The Hero:

a Study in Tradition, Myth and Drama. By Lord Raglan. Pp. xi+311. (London: Methuen and Co., Ltd., 1936.) 10s. $6 d$. net.

Is this volume, Lord Raglan extends to a wider field the application of certain critical principles which he formulated in his presidential address to Section $\mathrm{H}$ (Anthropology) of the British Association. He denies the validity of the methods by which tradition is made the ground of inference as to events in the past, of which documentary evidence, literary or archæological, has not survived. He maintains that tradition, still less the elusive "folk memory", does not endure for more than at most one hundred and fifty years, and that anything claiming to transcend that period is fictitious.

Lord Raglan is not content to rest in destructive criticism. He passes on to show how the 'standardized' heroic traditions came into being. They are, he holds, the concrete part of a ritual, which in most instances can be seen to underlie them, and when regarded at this angle, conforms to the pattern of fertility and cognate rites of an early form of community.

Lord Raglan argues his case ably and well. At the same time, there is something to be said in favour of tradition. Lord Nelson and Napoleon did exist, even though they may appear side by side with the entirely imaginary characters of the folk-drama. Lord Raglan, presumably, would feel constrained to deny their existence, if documentary evidence were absent. That the argument from tradition has sometimes been carried to absurd lengths does not alter the fact that it has served as a useful pointer in archæological argument, as, for example, in the instance of Crete, Troy and other sites of Greek heroic legend. Often such legends must be taken as doing no more than provide the archæologist with a memoria technica for cultural movements, contacts and development revealed by archæological research. The argument from tradition, like many other useful things, including Lord Raglan's counter, must be employed with discretion.

\section{Wave Mechanics:}

Elementary Theory. By Prof. J. Frenkel. (The International Series of Monographs on Physics.) Second edition. Pp. $\mathrm{x}+312$. (London: The Oxford University Press, 1936.) 20s. net.

THIS new edition needs little introduction to readers of NATURE. For the benefit of those who have not studied it, it may be said at once that it is one of the best introductions to wave mechanics extant complete in itself, clear in development, and not overburdened with mathematical symbolism. The seven sections into which the book is divided deal respectively with light, matter, wave mechanics of a particle, wave mechanics of a system of particles, statistical mechanies, applications to metal theory, heat motion and radiation, and the last section, which is new, is concerned with the theory of chemical forces. Small errors and misprints have been eliminated. The word 'elementary' must not be misunderstood, as, although mathematical developments are not over-emphasized, the work cannot be read with profit by a student who does not possess that knowledge of mathematics necessary to a student of physics of honours grade.

"A little philosophy inclineth Man's mind to atheism; but depth in philosophy bringeth men's minds about to religion." So far Bacon ; and some of the enthusiasts who have made far-reaching, and possibly hurried, deductions from Heisenberg's uncertainty principle, might profitably consider the brief, but important section in which Prof. Frenkel deals with Heisenberg's theory of the uncertainty relation to the role of the observer.

\section{Neuroembryology :}

Neuroembryology: an Experimental Study. By Prof. S. R. Detwiler. (Experimental Biology Series.) Pp. $x+218$. (New York: The Macmillan Co., 1936.) 16s. net.

A Bоok which gives the exact position of a research subject is always valuable, provided it is accompanied as here by a full literature list. It discusses the factors influencing the growth of nerves, the proliferation of nerve cells and the capacity of the nervous system to adapt itself in response to changed conditions. By experimentation, imposed upon a knowledge of the morphological changes, the dynamics of the developing organism are studied. The data are collected by the examination of the effects in regenera. tion, by surgical means and by grafting, these leading to hypotheses of the agencies underlying the normal architecture; here the work of Ross Harrison in the last forty years is highly distinguished. Then later there is the study of the growth of nerves in vitro, which favours mechanical factors rather than those dependent on hormones, chemotaxis or electrical agents. The whole story of the use and present position of the subject is here told in a pleasant and easy manner, such as will undoubtedly encourage new workers to enter this difficult field.

\section{Ebulliometry}

By Prof. Wojciech Swiettosławski. Pp. $x+196$. (Krakow: Jagellonian University Press, 1936.)

THIs is an account of the method of precise boiling point measurements based on the Cottrell principle which has been developed by Prof. Swietosławski and his students since 1925 and applied to a number of physico-chemical problems. Numerous forms of apparatus are described with full experimental details, and this monograph should be useful in directing attention to an experimental technique which has perhaps not yet been recognized in Great Britain at its true worth.

It is a little unfortunate that the translator appears to be more familiar with the idiom of the French language than with English; thus it requires a moment's thought to reveal the significance of "dosing vessels". In general, however, the meaning is clear, and this monograph will be valued not only for its detailed exposition of the experimental methods but also for the discussion of a wide range of scientific and technical problems in which boiling point methods can be used.
S. S. 